\title{
Epigenetic regulation of transcription factor promoter regions by low-dose genistein through mitogen-activated protein kinase and mitogen-and-stress activated kinase 1 nongenomic signaling
}

\author{
Linda Yu', Kyle Ham¹, Xiaohua Gao', Lysandra Castro', Yitang Yan¹, Grace E. Kissling², Charles J. Tucker³,
} Norris Flagler ${ }^{4}$, Ray Dong ${ }^{1}$, Trevor K. Archer ${ }^{5}$ and Darlene Dixon ${ }^{1 *}$ (D)

\begin{abstract}
Background: The phytoestrogen, genistein at low doses nongenomically activates mitogen-activated protein kinase p44/42 (MAPK $\left.{ }_{p 44 / 42}\right)$ via estrogen receptor alpha (ERa) leading to proliferation of human uterine leiomyoma cells. In this study, we evaluated if MAPK $\mathrm{p}_{\mathrm{p} 4 / 42}$ could activate downstream effectors such as mitogen- and stressactivated protein kinase 1 (MSK1), which could then epigenetically modify histone $\mathrm{H} 3$ by phosphorylation following a low dose $(1 \mu \mathrm{g} / \mathrm{ml})$ of genistein.

Results: Using hormone-responsive immortalized human uterine leiomyoma (ht-UtLM) cells, we found that genistein activated MAPK $\mathrm{p}_{44 / 42}$ and MSK1, and also increased phosphorylation of histone $\mathrm{H} 3$ at serine10 (H3S10ph) in ht-UtLM cells. Colocalization of phosphorylated MSK1 and H3S10ph was evident by confocal microscopy in htUtLM cells $(r=0.8533)$. Phosphorylation of both MSK1and H3S10ph was abrogated by PD98059 (PD), a MEK1 kinase inhibitor, thereby supporting genistein's activation of MSK1 and Histone H3 was downstream of MAPK ${ }_{p 44 / 42}$. In proliferative (estrogenic) phase human uterine fibroid tissues, phosphorylated MSK1 and H3S10ph showed increased immunoexpression compared to normal myometrial tissues, similar to results observed in in vitro studies following low-dose genistein administration. Real-time RT-PCR arrays showed induction of growth-related transcription factor genes, EGR1, Elk1, ID1, and MYB (cMyb) with confirmation by western blot, downstream of MAPK in response to low-dose genistein in ht-UtLM cells. Additionally, genistein induced associations of promoter regions of the above transcription factors with H3S10ph as evidenced by Chromatin Immunoprecipitation (ChIP) assays, which were inhibited by PD. Therefore, genistein epigenetically modified histone H3 by phosphorylation of serine 10, which was regulated by MSK1 and MAPK activation.
\end{abstract}

Conclusion: Histone H3 phosphorylation possibly represents a mechanism whereby increased transcriptional activation occurs following low-dose genistein exposure.

Keywords: Epigenetic, Histone H3, Leiomyoma, MAPK ${ }_{p 44 / 42}$, MSK1

(Continued on next page)

\footnotetext{
* Correspondence: dixon@niehs.nih.gov

${ }^{1}$ Molecular Pathogenesis Group, National Toxicology Program (NTP)

Laboratory, Division of the NTP (DNTP), National Institute of Environmental

Health Sciences (NIEHS), National Institutes of Health (NIH), U.S. Department

of Health and Human Services (HHS), Research Triangle Park, North Carolina

27709, USA

Full list of author information is available at the end of the article
} 


\begin{abstract}
(Continued from previous page)
Abbreviations: ChIP, Chromatin immunoprecipitation; EGR1, Epidermal growth factor receptor 1 gene; Elk1, Member Of ETS oncogene family; ERa, Estrogen receptor alpha; ERß, Estrogen receptor beta; H3S10ph, Histone H3 phosphorylated at serine10; ht-UtLM, Human uterine leiomyoma; ID1, Inhibitor of DNA Binding 1; IGF 1, Insulin-

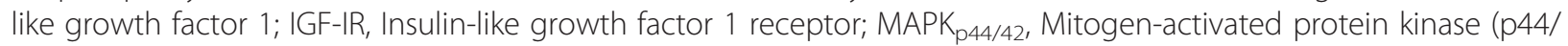
42); MSK1, Mitogen- and stress-activated protein kinase 1; MYB (cMYB), V-Myb Avian Myeloblastosis; PD, PD98059; PDGF, Platelet-derived growth factor; qRT-PCR, Quantitative real time polymerase chain reaction; RT-PCR, Real time polymerase chain reaction
\end{abstract}

\section{Background}

Uterine leiomyomas "fibroids" are the most common tumors found in the genital tract of both premenopausal and postmenopausal women [1]. Even though these tumors are benign, uterine leiomyomas have a significant impact on the reproductive health of women due to their high incidence and lack of proven treatment options other than surgery [2]. There is very little known about the etiology or pathogenesis of these tumors, although it is known that they are hormonally regulated and many growth factors upstream of MAPK appear to play a major role in their growth [3]. The role of certain environmental estrogens in the pathogenesis of fibroids remains to be elucidated [4].

Genistein is a soy-derived phytoestrogen that has been shown to be an anti-cancerous agent, and reported to have a stimulatory or inhibitory effect on cell proliferation depending on its concentration [5-7]. The plasma levels of genistein in humans ranges from $10 \mathrm{nM}$ to $10 \mu \mathrm{M}$ [8]. In previous in vitro experiments in our laboratory, we have found that a low concentration $(1 \mu \mathrm{g} /$ $\mathrm{ml} ; 3.7 \mu \mathrm{M})$ of genistein, which is in the range of human exposures, stimulates growth of human uterine leiomyoma cells [7, 9]. Genistein is known for interacting with estrogen receptors alpha and beta (ER $\alpha$ and ER $\beta$ ) [10]. Studies suggest that the effects observed with genistein and other estrogens, and classical ER binding is dependent on the ER type and content of the ER in target tissues or cells of interest $[9,11,12]$. It is thought that the effects observed in tissues whereby there is an abundance of ER $\alpha$, as seen in the uterus and uterine cells, may be different from those observed in the prostate gland and ovary, in which ER $\beta$ is dominant $[11,12]$. Therefore, the varying levels of ER $\alpha$, or and ER $\beta$ within a given tissue or cell type are thought to dictate the responses of those tissues to estrogens or estrogen mimics $[9,10]$. It is speculated that the tissue-specific effects observed in response to estrogens or estrogenic compounds may also be driven by the estrogen concentration, balance of ER $\alpha$ versus $E R \beta$, and variation in transcription factors, coactivators and corepressors activated by ER $\alpha$ or $\operatorname{ER} \beta[11,12]$. Estrogen also exerts biological effects through membrane-associated receptors, such as ER $\alpha 36, E R \alpha 46$ and G protein-coupled estrogen receptor 1, GPER1, to initiate nongenomic events leading to cell proliferation [13]. We have previously reported that our uterine leiomyoma cells express both ER $\alpha$ and ER $\beta$ receptors with higher expression levels of ER $\alpha$ [9, 14]. Also, we have reported that $E R \alpha$ is involved in transient nongenomic activation of ERK/mitogen activated protein kinase (MAPK) by genistein $(1 \mu \mathrm{g} / \mathrm{ml})$ via its early induction of ER $\alpha$ and IGF-IR associations, leading to uterine leiomyoma cell proliferation [9].

MAPKs are protein kinases (or enzymes) that convert stimuli into a wide range of cellular responses [15]. MAPK pathways regulate gene expression, mitosis, differentiation and proliferation $[15,16]$. MSK1 (mitogenand stress-activated protein kinase) is a kinase that is activated as a result of phosphorylation by $\mathrm{MAPK}_{\mathrm{p} 44 / 42}$ in cells [17]. Histone H3 is involved in the structural modification of chromatin in eukaryotic cells, and is also thought to play a role in the long-term regulation of genes in cells. MSK1 is downstream of MAPK [17], and activation of Histone $\mathrm{H} 3$ can occur as a result of MSK1 phosphorylation. Hyper-phosphorylation of histone $\mathrm{H} 3$ on serine 10 site may cause cell chromatin structural changes to open transcriptional factor promoter regions leading to enhanced gene transcription, the outcome of which is cell and stimulus dependent, and can range from cellular differentiation and cell proliferation to cell transformation and neoplasia [18-20].

In this study, an in vitro experiment was done to determine if genistein could affect Histone H3 phosphorylation via MSK1 by MAPK activation in immortalized human uterine leiomyoma (ht-UtLM) cells. We also used immunohistochemistry to determine the differential expression of MSK1 and Histone H3 in leiomyoma and patient matched myometrial tissues during the proliferative (estrogenic) menstrual cycle phase. An understanding of how genistein regulates epigenetic changes through MAPK/MSK1/H3 activation will help in revealing the biological effects of environmental estrogens and their nongenomic regulation of transcription factors and transcriptional activation in fibroids and other hormonally regulated disease conditions. 


\section{Results}

Genistein stimulates activation of MSK1 and H3S10ph through MAPKp44/42 phosphorylation

Previously, MAPK $\mathrm{M} 44 / 42_{2}$ was reported to be constitutively activated in human uterine leiomyoma cells [9], and MEK1 specifically phosphorylates MAPK $_{\mathrm{p} 44 / 42}$ [21]. We examined whether the increased levels of phosphorylated $\mathrm{MAPK}_{\mathrm{p} 44 / 42}$ in ht-UtLM cells induced by genistein at $1 \mu \mathrm{g} / \mathrm{ml}$ could activate downstream MSK1 and lead to Histone H3 phosphorylation. We found there was increased expression levels of phosphorylated $\mathrm{MAPK}_{\mathrm{p} 44 / 42}$ in ht-UtLM cells, and there was also increased MSK1 and Histone $\mathrm{H} 3$ activation downstream of $\mathrm{MAPK}_{\mathrm{p} 44 / 42}$ following genistein exposure at $1 \mu \mathrm{g} / \mathrm{ml}$ at $10 \mathrm{~min}$ for phosphorylated MAPK $\mathrm{p} 44 / 42$, and 10 and $60 \mathrm{~min}$ for phosphorylated
MSK1 (pMSK1) and H3S10ph (by using a specific antibody targeting Histone $\mathrm{H} 3$ at phosphorylated serine 10 site only), respectively, in the cells (Fig. 1a and b). The increased phosphorylation of $\mathrm{MAPK}_{\mathrm{p} 44 / 42}$ induced by genistein in ht-UtLM cells was attenuated by a MEK1 inhibitor, PD, and the activation of MSK1 and H3S10ph downstream of MAPK $_{\mathrm{p} 44 / 42}$ were also inhibited by PD (Fig. 1a and b), which would suggest that the phosphorylation of MSK1 and H3S10ph in ht-UtLM cells was mediated by $\mathrm{pMAPK}_{\mathrm{p} 44 / 42}$.

\section{Phospho-MSK1 and H3S10ph are highly expressed in} tumors compared to myometrial tissues from women in the proliferative (estrogenic) phase of the menstrual cycle The phospho-MSK1 was intensively expressed in all 16 patient leiomyoma and myometrial tissues (Fig. 2a), with

\section{a}

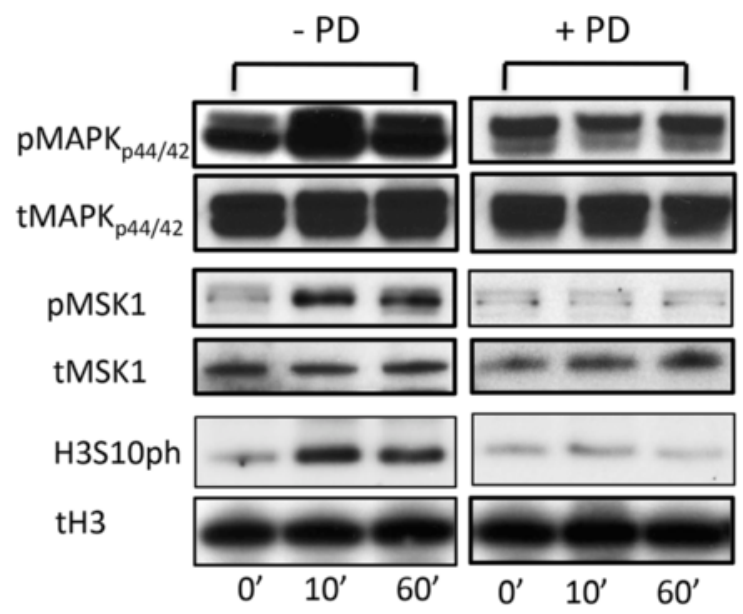

b

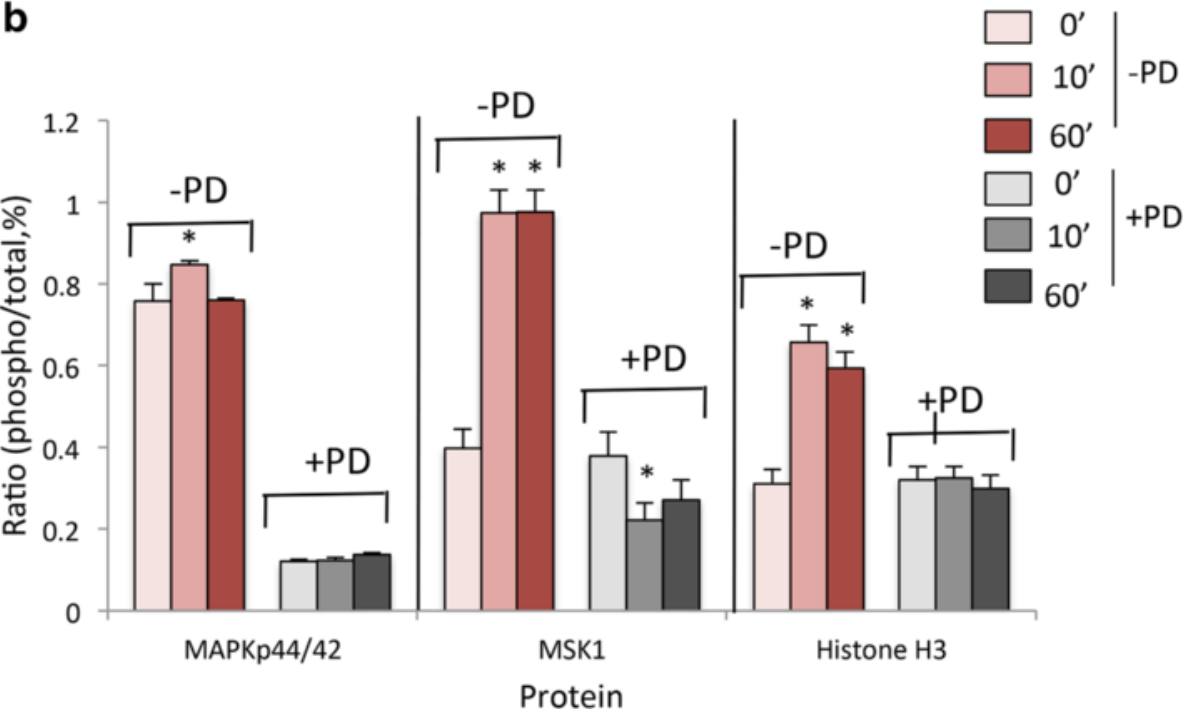

Fig. 1 Differential expression of phosphorylated MAPK ${ }_{p 44 / 42}, M S K 1$, and H3 in ht-UtLM cells. a Western blots of total (t) and phosphorylated ( $p$ )

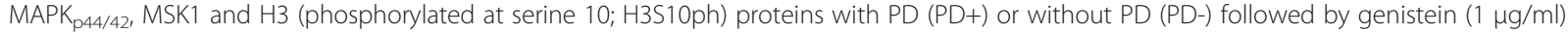
treatment for 0,10 or $60 \mathrm{~min}$. b Comparison of ratio of densitometric band intensities of phosphorylated/total (p/t, \%) proteins in ht-UtLM cells. Data shows the mean+/-SEM of three independent experiments; ${ }^{*} p<0.05$ versus 0 min 


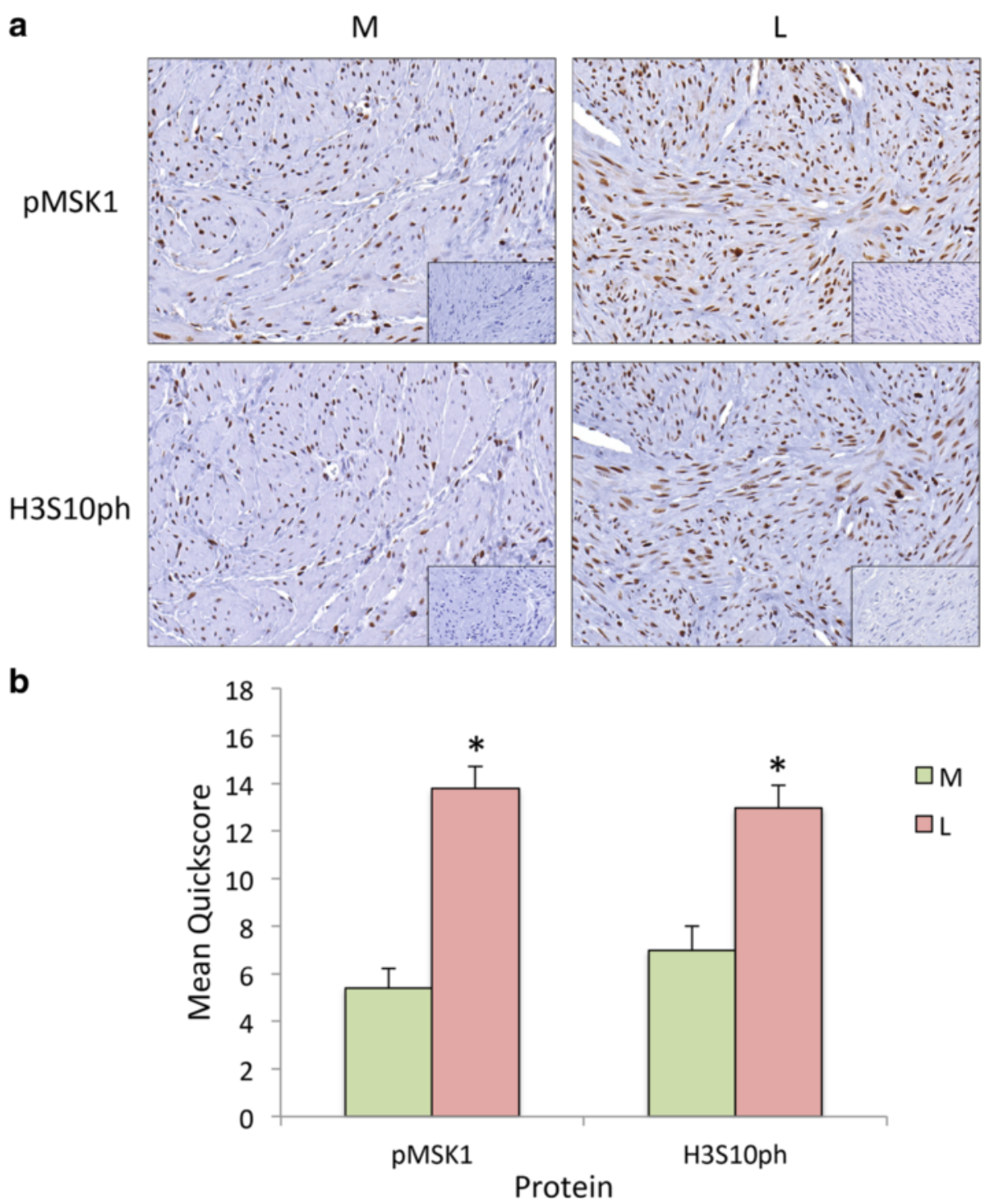

Fig. 2 Increased immunolocalization of phosphorylated MSK1 and H3S10ph in leiomyoma (L) and myometrial (M) tissues. a The immunohistochemical staining was performed on $L$ and matched $M$ tissue samples from 16 patients to determine the phosphorylated (p) MSK1, and H3S10ph expression patterns. Inset: Negative control with normal rabbit lgG. b The bar graph shows the mean+/-SEM of the quickscores from 16 patient-matched samples in the proliferative phase of the menstrual cycle; ${ }^{*} P<0.001 \mathrm{~L}$ versus $M$ tissue

much higher expression of phospho-MSK1 in the tumors compared to patient matched myometrial tissue samples (Fig. 2b). The H3S10ph was also highly expressed in leiomyoma and myometrial tissues (Fig. 2a), with an increased level in the tumor compared to patient matched myometrium (Fig. 2b). However, there were no differential expression of total MSK1 and Histone H3 between leiomyoma and myometrial tissues. Under the influence of estrogen in vivo, tissue samples showed an overall overexpression of activated MSK1 and H3S10ph similar to ht-UtLM cells exposed to a low-dose of genistein, an estrogen mimic.
Increased colocalization of phosphorylated MSK1 and $\mathrm{H} 3 \mathrm{~S} 10 \mathrm{ph}$ induced by genistein $(1 \mu \mathrm{g} / \mathrm{ml})$ in ht-UtLM Cells and the effects were abolished by PD

Due to increased expression of $\mathrm{pMAPK}_{\mathrm{p} 44 / 42}$, pMSK1and H3S10ph by western blotting, we were interested in determining whether phospho-MSK1 and H3S10ph were colocalized following genistein administration using immunofluorescence staining and confocal microscopy. As shown in Fig. 3a, confocal microscopy revealed that genistein rapidly increased phosphorylation levels of MSK1 and H3S10ph in the nuclei of ht-UtLM cells at $10 \mathrm{~min}$, and these effects were abrogated in the presence of PD pre-treatment. Similar 


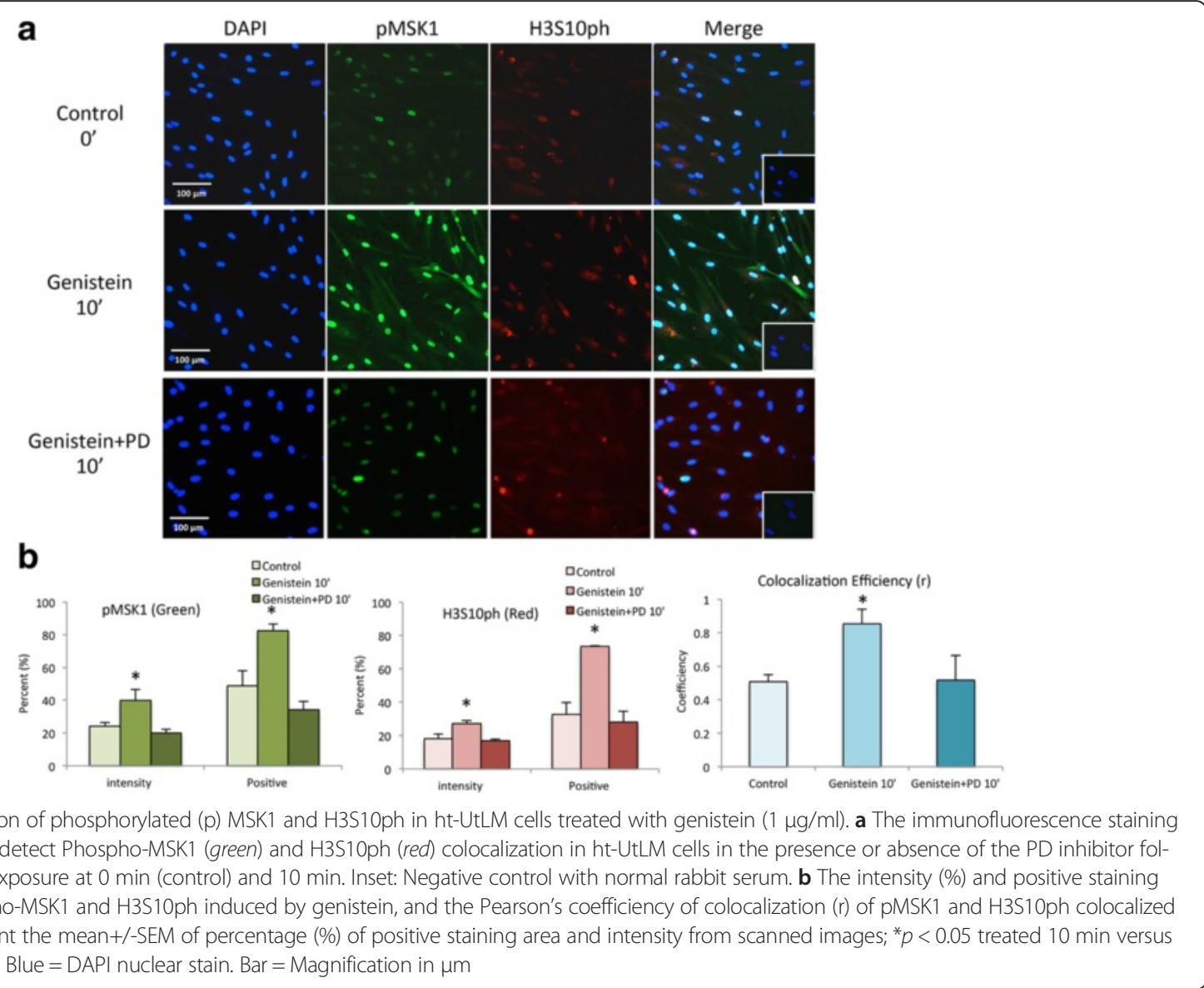

effects for MSK1 and H3S10 activation were seen up to $60 \mathrm{~min}$ and were also inhibited by PD in ht-UtLM cells (see Additional file 1). Confocal microscopy further indicated that there was an overlapping of green (pMSK1) and red (H3S10ph), and there was enhanced phospho-MSK1 and H3S10ph colocalization $(r=0.8533$ versus control, $r=0.5067)$ in the nuclei of ht-UtLM cells following $10 \mathrm{~min}$ of genistein administration, and decreased colocalization $(r=0.516)$ after PD pre-treatment (Fig. 3b).

\section{Genistein enhances cell proliferation-related transcription factor gene expression}

To identify the transcription factors possibly involved in genistein modulation of cell proliferation previously observed in our earlier studies in UtLM cells treated with genistein $(1 \mu \mathrm{g} / \mathrm{ml})$ but not in UtSMC [9], we used a custom designed 384-well real-time RT PCR array plate coated with 12 predispensed transcriptional factor genespecific primer sets (SABiosciences) and the GAPDH housekeeping gene as a control. The 12 genes were selected based on their up- or down regulation following genistein treatment using a Human Transcription Factors $\mathrm{RT}^{2}$ Profiler PCR Array (Qiagen) containing 84 genes (see Additional file 2). Total RNA isolated from ht-UtLM cells stimulated with genistein $(1 \mu \mathrm{g} / \mathrm{mL})$ for $24 \mathrm{~h}$ was used for the array. We identified increases $(\mathrm{P} \leq$ 0.0003-0.0575) in expression of seven transcription factor genes, and decreased expression of one transcription factor gene (ESR1) in genistein stimulated ht-UtLM cells compared to non-stimulated cells (Fig. 4a and b). Four transcription factor genes had a $>2$-fold change: EGR1 (10.41), ELK1 (3.57), ID1 (5.19), and cMyb (2.15) (Fig. 4a), which would be further confirmed by western blot. These results suggest that genistein may have modulated cell growth through enhanced specific transcriptional regulatory mechanisms in ht-UtLM cells. As shown in Fig. 4b, EGR1 expression in genisteinstimulated ht-UtLM showed the highest significant increase in mRNA levels, with modest, but significant increases in mRNA levels of ID1 and cMyb, and a marginally significant increase in ELK1 compared with unstimulated cells.

Increased protein expression of cell proliferation related transcription Factor was confirmed

We next confirmed EGR1, Elk1, ID1, and cMyb protein expression in ht-UtLM cells at different time points. 
a

\begin{tabular}{|l|r|r|}
\hline \multicolumn{1}{|c|}{ Symbol } & Fold Change & \multicolumn{1}{c|}{ p-value } \\
\hline ESR1 & 0.8592 & 0.036023 \\
\hline FOS & 1.5722 & 0.011574 \\
\hline ID1 & 5.1912 & 0.000302 \\
\hline JUN & 1.2444 & 0.081172 \\
\hline CREB1 & 0.8862 & 0.308538 \\
\hline ATF3 & 1.9627 & 0.00086 \\
\hline E2F1 & 1.4143 & 0.07158 \\
\hline EGR1 & 10.4084 & 0.018039 \\
\hline ELK1 & 3.5681 & 0.057596 \\
\hline MYB & 2.1498 & 0.009936 \\
\hline MYC & 1.4687 & 0.017885 \\
\hline STAT3 & 1.2254 & 0.126895 \\
\hline
\end{tabular}

b

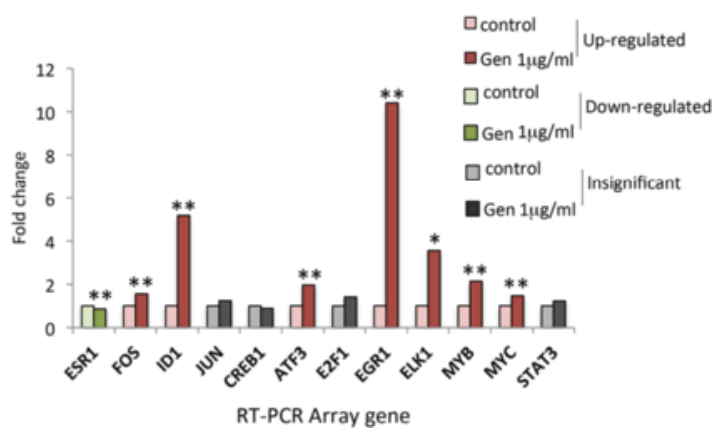

Fig. 4 Differential expression of transcription factor genes induced by genistein $(1 \mu \mathrm{g} / \mathrm{ml})$ in ht-UtLM cells at $24 \mathrm{~h}$. a The fold changes by RealTime PCR array for ht-UtLM cells. $\mathbf{b}$ Plot of fold changes of transcription factor genes in response to genistein treatment in ht-UtLM cells. Data represent the mean+/-SEM of three independent experiments. ${ }^{* *} p \leq 0.0003-0.0360$ versus control (no treatment); ${ }^{*} p=0.0575$

Total cell lysates obtained from cells stimulated with genistein $(1 \mu \mathrm{g} / \mathrm{mL})$ for 0,24 , and $48 \mathrm{~h}$ with or without PD were analyzed by western blotting for EGR1, Elk1, ID1, and cMyb expression. The cells stimulated with genistein had a significant increase in protein levels of EGR1, Elk1, ID1 and cMyb expression compared with unstimulated cells (Fig. 5). These results suggested that genistein could modulate cell proliferation-related transcription factor genes through specific transcriptional regulatory mechanisms in ht-UtLM cells.

\section{Genistein enriches the promoter region of transcriptional factors mediated by histone $\mathrm{H} 3$ phosphorylation}

To further determine whether the histone H3ser10 phosphorylation site was associated with the promoter regions of genistein-induced transcription factors, EGR1, Elk1, ID1, and cMyb following genistein exposure in ht-UtLM cells, the promoter regions of the above transcription factors were examined using ChIP assays. The primers as shown in Table 1 were picked through searches of the four transcription factor gene promoter regions in databases. The gene promoter regions that co-precipitated with antiH3S10ph antibody were determined by qRT-PCR. Increased levels of EGR1, Elk1, ID1 and cMyb promoter regions were observed; however, only the ID1 and $\mathrm{cMyb}$ promoter region enrichments were statistically significant. EGR1 and Elk1 promoter region enrichments were not statistically significant and this may have been due to variations in fold changes among the triplicates of ht-UtLM cells treated with genistein (Fig. 6). PD inhibited the enrichment of all four of these transcription factor promoter regions. These results suggest that the enrichment of the promoter regions following genistein administration was induced by phosphorylation of histone $\mathrm{H} 3$ at serine 10 and mediated by $\mathrm{MAPK}_{\mathrm{p} 44 / 42 \text {, with subse- }}$ quent MSK1 activation leading to gene transcription.

\section{Discussion}

In our previous studies, we have found that genistein at a concentration of $1 \mu \mathrm{g} / \mathrm{ml}$ stimulates proliferation of ht-UtLM cells [7]. We also reported that genistein at $1 \mu \mathrm{g} / \mathrm{ml}$ could directly activate classic ER gene transcription, upregulate estrogen-responsive genes, and is involved in transient nongenomic activation of ERK/ mitogen-activated protein kinase $\left(\mathrm{MAPK}_{\mathrm{p} 44 / 42}\right)$ via its early induction of ER $\alpha$ and IGF-IR associations, leading to cell proliferation [9]. In this study, we further evaluated if $\mathrm{MAPK}_{\mathrm{p} 44 / 42}$ could activate a downstream effector, such as MSK1, which may perhaps epigenetically modify histone $\mathrm{H} 3$ by phosphorylation following a low dose $(1 \mu \mathrm{g} / \mathrm{ml})$ of genistein exposure in ht-UtLM cells.

A wide range of genes has been shown to be upregulated or downregulated in uterine tissue of rats treated with genistein [22]. A number of studies have shown that tumorigenesis genes are transcriptionally silenced through modifications of promoter-associated histones as functions of expression of MAPK-mediated tumor progression [23-25]. Upregulated transcription by an epigenetic mechanism can involve phosphorylation of histone $\mathrm{H} 3$ via the activation of tumorigenic MAPK pathways [26]. Although the mechanisms by which these pathways regulate histone phosphorylation remains unknown, understanding the molecular link(s) between these pathways and the regulation of histone modification would provide new insights into the molecular basis of human uterine leiomyoma related alterations of gene expression through chromatin remodeling induced by estrogen or environmental estrogen mimics, like genistein.

In this study, we demonstrated that the $\mathrm{MAPK}_{\mathrm{p} 44 / 42} /$ ERK1/2 pathway can be activated by genistein in human uterine leiomyoma cells and lead not only to elevated 


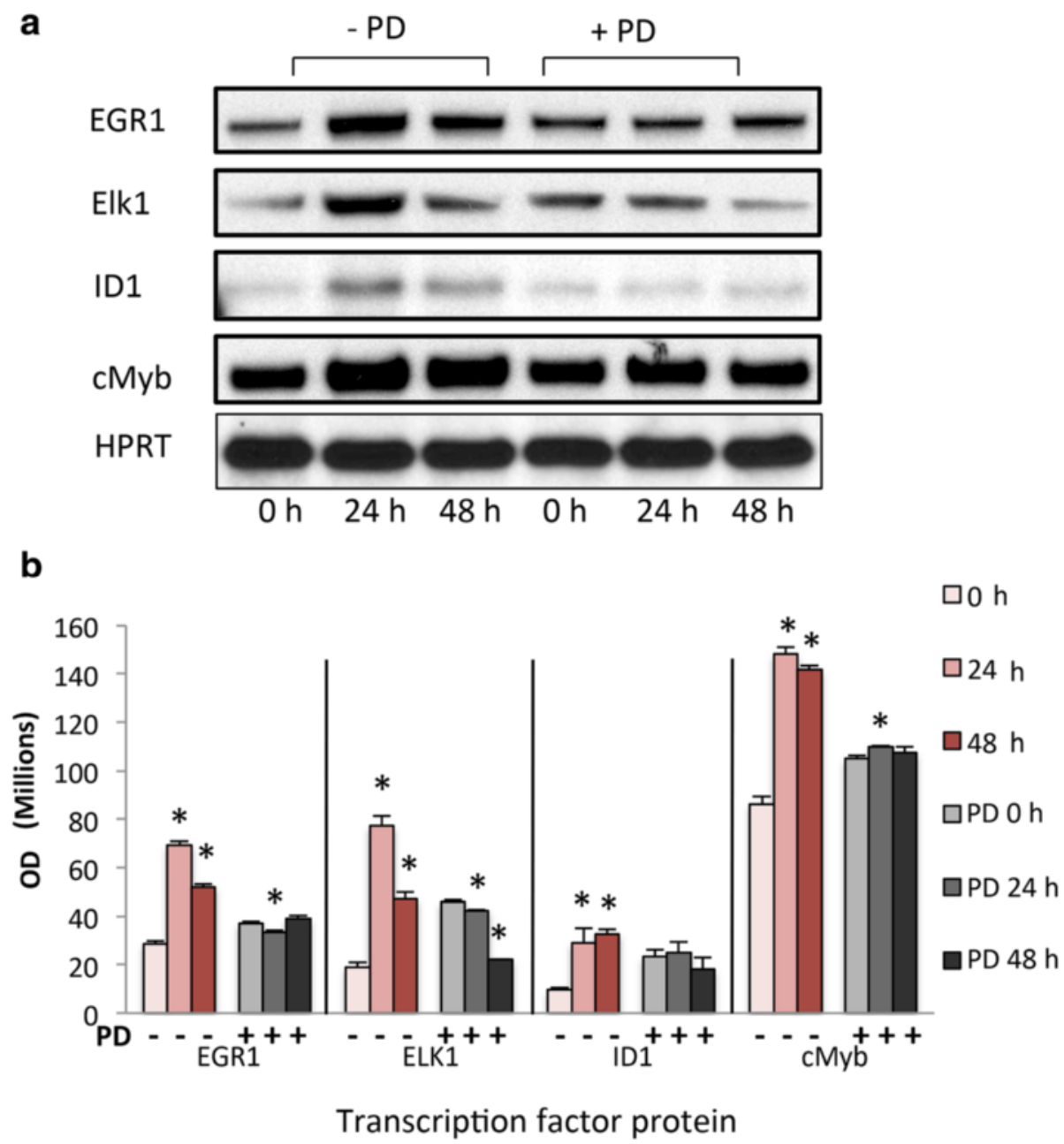

Fig. 5 Differential expression of transcription factor proteins induced by genistein $(1 \mu \mathrm{g} / \mathrm{ml})$ in ht-UtLM cells for 0,24 and 48 h. a Western blot of EGR1, Elk1, ID1 and MYB proteins in ht-UtLM cells stimulated with genistein with or without PD. Hypoxanthine-guanine phosphoribosyltransferase (HPRT) served as loading control. $\mathbf{b}$ Comparison of band intensities of transcription factor proteins in ht-UtLM cells. Data represent the mean + /-SEM of three independent experiments. ${ }^{*} \mathrm{p}<0.05$ versus $0 \mathrm{~h}$

levels of phospho-MAPK $\mathrm{p}_{44 / 42}$ but also to increased levels of downstream nucleosome effectors phosphorylated MSK1 and H3S10ph, and their colocalization. It has been proposed that histone $\mathrm{H} 3$ phosphorylation might result in a greater exposure of histone $\mathrm{H} 3$ to MSK1 [24]. The intensity and duration of signaling of MSK1 and histone H3 upon genistein stimulation correlates well with the activated $\mathrm{MAPK}_{\mathrm{p} 44 / 42}$ in the cells, which might indicate a higher level of chromosome dynamics [26] mediated by MAPK, and a more open chromatin structure compared to the untreated cells. The specificity of MAPK regulation of MSK/histone H3 expression was further confirmed through PD98059 suppression of $\mathrm{MAPK}_{\mathrm{p} 44 / 42}$ expression in these cells. Western blot analysis of total cell lysates obtained from cells treated with PD revealed inhibition of MAPK $\mathrm{M}_{\mathrm{p} 4}$ ${ }_{42}$ expression in ht-UtLM cells leading to abrogation of phosphorylation of MSK1 and H3S10ph induced by genistein.

Phosphorylation of MSK1 and histone H3 is an epigenetic mechanism altering gene expression [18]. Epigenetic alterations, including DNA methylation and histone acetylation and phosphorylation, might independently regulate gene expression of DNA sequences [27]. Alterations in epigenetic programming in the htUtLM cells may alter the timing of induction of genes by changing the chromatin landscape of MSK1 and histone H3 target genes upon genistein exposure. In the case of MAPK signaling in ht-UtLM cells, genistein increased phospho-MAPK $\mathrm{p} 44 / 42_{2}$ levels resulting in a high predilection for MSK1 and histone $\mathrm{H} 3$ phosphorylation at serine10 site that induced epigenetic changes that led to enrichment of promoter regions of immediate early response genes known to correspond to cell proliferation 
Table 1 Primers for the ChIP Assays

\begin{tabular}{ll}
\hline Primer Name & Sequence \\
\hline EGR1-F & CCCTCACCACAAGGACCATT \\
EGR1-R & AAGCTGATTGCCCCAAGAGA \\
ELK1-F & CCCCCCATCCTCAGACATTA \\
ELK1-R & AAGAAGGGCCATGTGACTCAA \\
ID1-F & GCAGAAGGCTCCTITACTITTCC \\
ID1-R & GTTATCAGCAGGTTCCGTITTCC \\
CMyB-F & CACTTCACAAAGGGTTCAGATACTCA \\
CMyB-R & CTGGCAAGATTCCCAATTGC \\
\hline
\end{tabular}

and tumorigenesis [25]. It was reported that MSK1 is recruited to promoters of target genes by transcription factors such as Elk1 and the progesterone receptor $[19,20,28]$. In the cells there is a change in transcription factors composition and activity, which may alter the dynamics of MSK1 recruitment to target promoters to activate histone $\mathrm{H} 3$ leading to chromatin structure alterations [18] and in turn increase target promoter expression levels during tumorigenesis.

Human gene expression is largely controlled at the level of transcription and post transcription. Involvement of transcriptional factors in different signal transduction pathways determines the level of expression of a specific gene. Abnormalities in transcription factors are associated with a number of human diseases [29]. The real-time PCR array, with twelve potential transcription factors from cell proliferation-related transcription factor gene families in this study, suggested that the enhanced activity of MSK1 and elevated levels of phosphorylated histone H3 contributed to significantly higher levels of four transcription factor genes (EGR1: 10.41-fold; Elk1: 3.57-fold; ID1: 5.19-fold; and cMyb: 2.15-fold) in genistein treated ht-UtLM cells relative to those cells

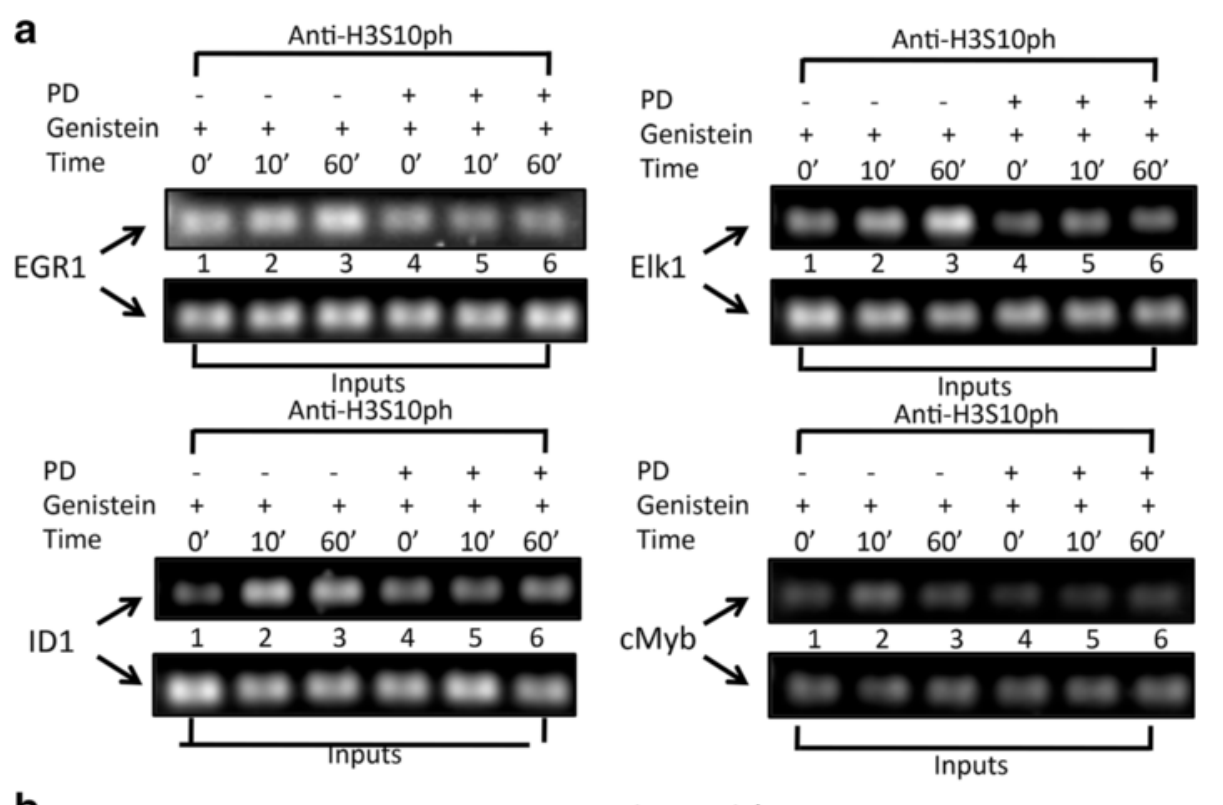

b

Promoter Region Enrichment

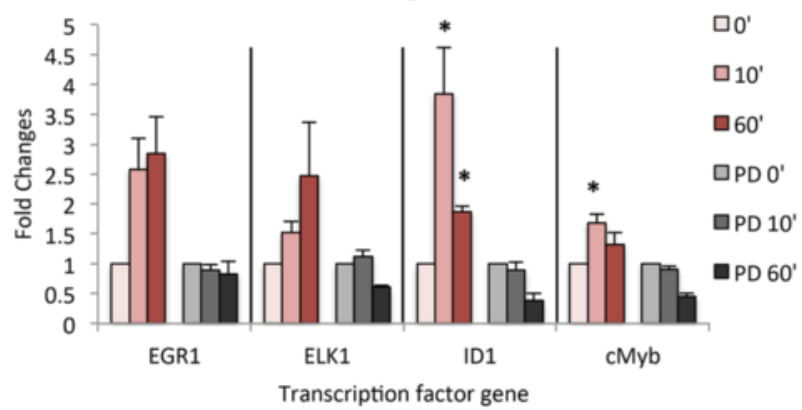

Fig. 6 Differential expression of promoter regions of transcription factor genes in ht-UtLM cells with PD or without PD followed by genistein $(1 \mathrm{\mu g} / \mathrm{ml})$. a DNA gel image of promoter regions of transcription factors in ht-UtLM cells (DNA captured by H3S10ph antibody) in ChIP assay. b Plot of fold changes of enrichment of promoter regions of transcription factor genes in response to genistein treatment in ht-UtLM cells with or without PD. Data represent the mean+/-SEM of three independent experiments. ${ }^{*} p<0.05$ versus 0 min 
without treatment. The differences in transcription factor expression before and after genistein induction may be a consequence of changes in the activated MSK1 and H3S10ph recruiting more MSK1 to the promoter regions, and further phosphorylation of histone $\mathrm{H} 3$ resulting in epigenetic changes in gene expression programming and genomic instability [28] in ht-UtLM cells.

To determine if the promoter regions of transcription factors are opened more due to chromatin structural alterations caused by histone $\mathrm{H} 3$ phosphorylation, we used anti-H3S10ph antibody, with EGR1, Elk1, ID1, and cMyb ( $>2$-fold) promoter sequences as targets, in ChIP assays and found enrichment of the above transcription factor promoter regions after genistein treatment, restricting the target input to the promoter regions present in the ht-UtLM cells compared to untreated cells. The inhibition by PD, a MAPK specific inhibitor, attenuated the genistein induced MSK1 and histone H3 activation, and paralleled the abrogation of the enrichment of the promoter regions. Confirmation studies by western blotting revealed that PD also reduced transcript levels of EGR1, Elk1, ID1, and cMyb. These four transcription factor proteins were highly expressed in the cells treated with genistein compared to non-treated cells, and this highly expressed level was attenuated by PD, which indicated that the MAPK pathway played a critical role in the chromatin remodeling process that resulted in higher levels of transcription factor expression possibly leading to increased cell proliferation as observed in our previous studies $[7,9]$.

EGR1, early growth response-1, is a Cys2-His2-type zinc-finger transcription factor. It is involved in a number of biological processes including cellular growth, proliferation, differentiation and matrix re-modeling. In response to smooth muscle injury, EGR1 may activate matrix remodeling genes and profibrotic genes such as TGF- $\beta$, PDGF, and Collagen 1 genes [29, 30], which have all been suggested as etiological factors involved in the pathogenesis of human uterine leiomyomas. The transcriptional factor of Elk1 belongs to the ternary complex factor (TCF) subgroup of the Ets family, which is a target of the MAPK cascade [31]. It was found in our previous gene array studies that the genes involved in IGFIR/MAPK signaling were upregulated in UtLM cells by estrogen, including MAPKs, MAPK kinases, transcriptional factor Elk1 and others all involved in cell cycle progression, proliferation, and cell survival [30]. The upregulation of Elk1 induced by genistein, in this study further confirms the involvement of the MAPK/MSK/ histone $\mathrm{H} 3$ pathway and cell proliferation transcription factors in hormonally driven leiomyoma development. There is evidence that Elk1 bridges the gap between SRF-mediated gene transcription, EGR1 and the Raf/
MEK/ERK pathway to promote cell proliferation [29]. ID1, the helix-loop-helix transcription factor, also enhances cell proliferation. Its expression has been associated with the induction of tumor cell growth and promotion of cell survival. ID1 protein is frequently overexpressed in over 20 types of cancer, supporting its role in the tumorigenesis of a wide range of tissues [32]. ID1 mRNA levels are significantly increased in uterine cervical cancers [33]. Also, there is a report showing that the expression of ID1 is tightly regulated by estrogen in the mouse uterus [34]. Our study is the first study to reveal ID1 expression in human uterine leiomyoma cells downstream of histone $\mathrm{H} 3$ phosphorylation induced by genistein. Therefore, ID1 might work in uterine leiomyoma tumorigenesis through histone $\mathrm{H} 3$ activity. As a key regulator of proliferation, differentiation and cell fate, the cMyb transcription factor regulates the expression of hundreds of genes and in turn is regulated by numerous pathways and protein interactions. One of the most unique features of cMyb is the extremely complex nature of its regulation. The expression of the $\mathrm{cMyb}$ gene is regulated at several levels, including a sophisticated control of transcriptional elongation and that may be regulated by transcription factors or by the estrogen receptor alpha [35]. The increased expression of $\mathrm{cMyb}$ in ht-UtLM cells after genistein treatment indicates that its upregulation may be mediated through an estrogen receptor-MAPK/MSK1/histone H3 pathway.

\section{Conclusions}

In conclusion, we demonstrate the epigenetic regulation of transcription factor promoter regions by $\mathrm{MAPK}_{\mathrm{p} 44 / 42}$ through MSK1 and histone-H3 activation in human uterine leiomyoma cells exposed to genistein $(1 \mu \mathrm{g} / \mathrm{ml})$ (Fig. 7). These genistein-induced transcriptional activities may contribute to upregulation of genes involved in the increased proliferative properties of these cells observed in our earlier studies. The genistein exposed cells had changes in the histone $\mathrm{H} 3$ phosphorylation epigenetic program, which may have contributed to alterations in induced transcription factor gene expression responses observed. Moreover, the increased activity of MSK1 through MAPK phosphorylation in the cells contributes to the enhanced steady state levels of histone H3 phosphorylation. These changes in histone modification likely contribute to a less condensed chromatin structure in ht-UtLM cells. It has been reported that MSK1 and histone H3 serine 10 phosphorylation are required for tumor promoter induced cell proliferation and transformation [25, 36]. The contribution of MSK1 activity and histone $\mathrm{H} 3$ phosphorylation to chromosomal dynamics in human uterine leiomyoma cells might be a therapeutic target or intervention site for 


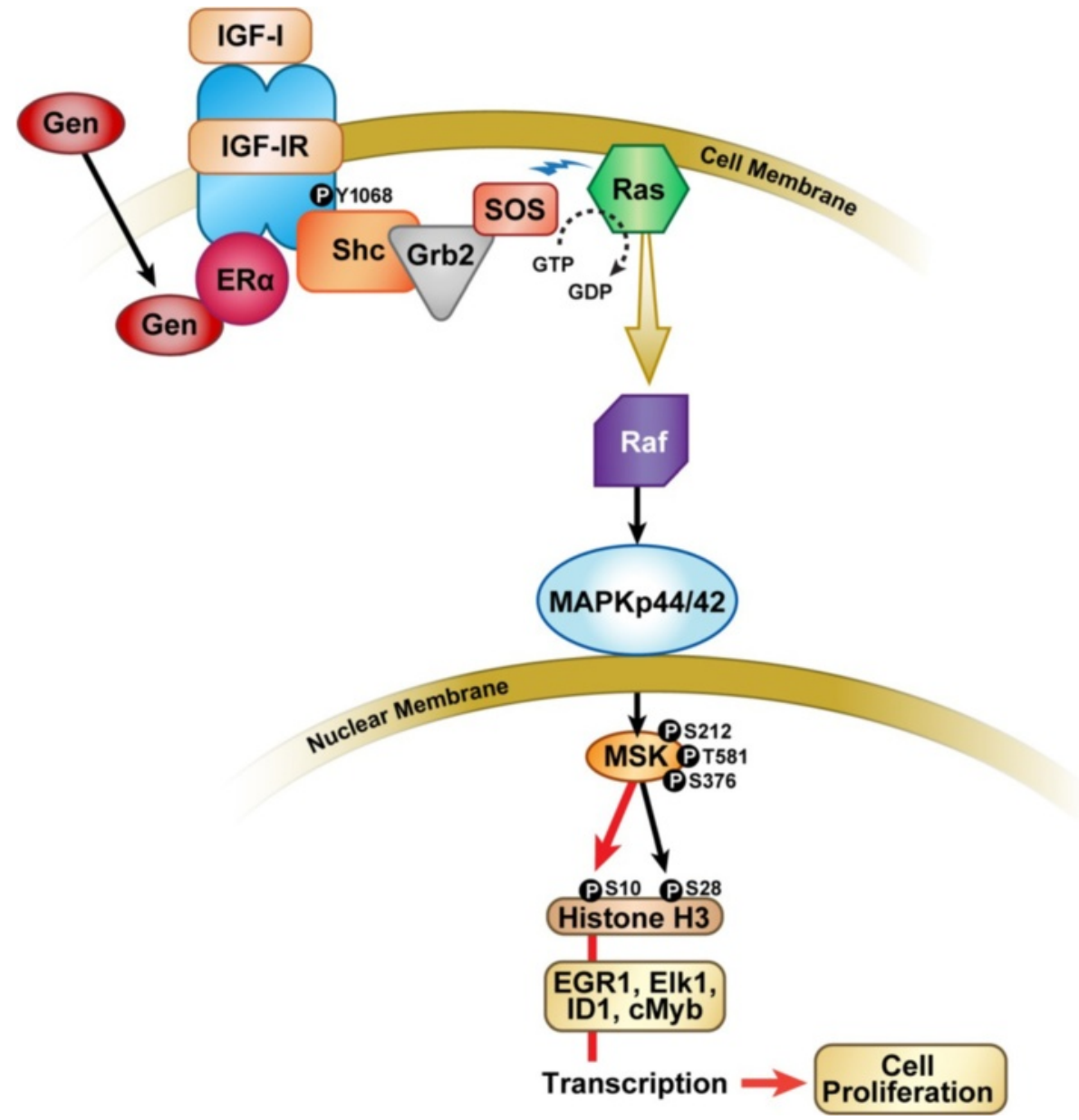

Fig. 7 Schematic illustration of MAPK/MSK1/Histone H3 pathway on target gene transcription. The MAPK/MSK1/Histone3 pathway induced by genistein via nongenomic transient interactions of ERa with receptor tyrosine kinases (IGF-IR) and activation of MAPK $\mathrm{p}_{\mathrm{p} 4 / 42} /$ ERK1/2 [9], with recruitment and phosphorylation of MSK1 and activation of Histone H3 leading to enrichment of promoter regions of transcription factors EGR1, Elk1, ID-1 and cMyb and the genes transcription in human uterine leiomyoma (ht-UtLM) cells

clinical fibroids stimulated to grow by endogenous and/ or environmental estrogens.

\section{Methods \\ Cells}

Ht-UtLM cells were previously established in our lab [14] and were grown to $80 \%$ confluency in Minimum Essential Medium (MEM) (Gibco) Containing supplements. The medium was later switched to charcoal/ dextran stripped Fetal Bovine Serum (FBS) (Sigma) in Dulbecco's modified Eagle Medium/Nutrient Mixture F12 Ham (DMEM-F12) (Gibco) without phenol red for $24 \mathrm{~h}$ prior to treatment with $1 \mu \mathrm{g} / \mathrm{ml}$ of genistein (Sigma) and/or $50 \mu \mathrm{g} / \mathrm{ml}$ of MEK1 inhibitor PD98059 (PD) (Cell Signaling), with pretreatment of PD for $2 \mathrm{~h}$.

\section{Western Blot}

Cell lysates containing total protein of cells were harvested in RIPA buffer [9] at 0,10 , and $60 \mathrm{~min}$ after treatment with genistein. The lysate $(30 \mu \mathrm{g} /$ well $)$ samples were loaded onto a 4-12 \% Bis Tris Gel and then transferred to a PVDF membrane. Western blotting was performed as previously described [37]. The primary antibodies (incubated overnight at $4{ }^{\circ} \mathrm{C}$ ) used were: rabbit polyclonal anti-MAPK $\mathrm{p} 44 / 42_{2}$ and anti-phosphoMAPK $_{\mathrm{p} 44 / 42}$ (Cell Signaling), rabbit polyclonal antiMSK1 (Santa Cruz Biotechnology), rabbit polyclonal anti-Phospho-MSK1 (Cell Signaling), rabbit polyclonal anti-Histone-H3 (Cell Signaling), and rabbit monoclonal anti-Phospho-Histone-H3Ser10 (Cell Signaling). The secondary antibodies used were: donkey anti-rabbit horseradish peroxidase conjugated antibody (GE Health Care) $1 \mathrm{~h}$ at room temperature (r.t.), rabbit polyclonal anti-EGR1, Elk1, and cMyb (Cell Signaling) and rabbit polyclonal anti-ID1 (Santa Cruz) which all incubated overnight at $4{ }^{\circ} \mathrm{C}$ to confirm real-time PCR array results as to whether the transcriptional factor gene expression levels induced by genistein also lead to the protein 
expression level changes. Detection was done for $1 \mathrm{~min}$ using ECL Western blotting reagents (GE Health Care). Comparison of ratio (\%) of densitometric band intensities (FluorChem ${ }^{\mathrm{TM}}$, Alpha Innotech) of phosphorylated to total proteins in control and ht-UtLM cells following genistein treatments were done.

\section{Immunhistochemistry}

Uterine leiomyoma and patient matched myometrial tissues were obtained from 16 patients ranging from 41 to 49 years of age in the proliferative (estrogenic) phase of the menstrual cycle. The tissue slides were deparaffinized, rehydrated, peroxidase blocked, and antigen retrieved [38]; then the tissues were incubated with specific primary antibodies (overnight at $4{ }^{\circ} \mathrm{C}$ ): antiphospho-MSK1 and anti-H3S10ph (mentioned earlier in the Western blotting section), or with non-immune rabbit serum (negative control) (Jackson Immuno Research) at the same concentration as the primary antibodies. The secondary antibody $(1 \mathrm{~h}$ at r.t., Vector Laboratories), label (Vector) and chromogen, 3,3' diaminobenzidine tetrahydrochloride (DAB) (Dako) were applied. Lastly, the tissues were rehydrated and coverslipped. Slides were then scanned using the Aperio ${ }^{\circ}$ Scanscope XT Digital Slide Scanner (Aperio Technologies). A semiquantitative numeric score incorporating overall percent of positive immunohistohemical staining and intensity of imunostaining was determined for leiomyoma and myometrial samples using the multiplicative quickscore method described by Detre et al. [39] and used by our lab previously $[40,41]$. The intensity of staining for each tissue was categorized as negative $=0$, weak $=1$, moderate $=2$, or intense $=3$. This number was multiplied by a number generated to indicate the percent of tissue showing positive immunostaining $(0-4 \%=1 ; 5-19 \%=2$; $20-39 \%=3 ; 40-59 \%=4 ; 60-79 \%=5 ; 80-100 \%=6$ ) to generate a quickscore number.

\section{Immunofluorescence (Confocal Microscopy)}

Immunofluorescence staining was performed to detect phospho-MSK1 and H3S10ph colocalization at 0, 10, and $60 \mathrm{~min}$ in ht-UtLM cells following genistein treatment $(1 \mu \mathrm{g} / \mathrm{ml})$ with or without PD inhibition. The cells were grown on glass-bottom dishes and fixed with ice cold $100 \%$ methanol (Avantor Performance), permeabilized with $0.2 \%$ Triton X-100 (Sigma), and blocked with $5 \%$ BSA (Sigma) and $0.1 \%$ gelatin (Sigma) in PBS. The cells were incubated overnight with primary phospho-MSK1 rabbit polyclonal (Cell Signaling) and phospho-Histone H3ser10 rabbit monoclonal antibodies (Alexa Flour 594 conjugated, Cell Signaling), followed by the secondary Alexa Fluor 488 goat anti-rabbit phosphoMSK1 secondary antibody (Invitrogen) and DAPI (Invitrogen). Non-immune rabbit serum (Jackson
Immunoresearch) at the same concentration as the primary antibodies, served as negative controls. Confocal images were taken on a Zeiss LSM780 (Carl Zeiss). The $561 \mathrm{~nm}$ laser line from a DPSS laser at $5 \%$ power was used for excitation of H3S10ph labeled with Alexa594. Subsequently, the $488 \mathrm{~nm}$ line of an Argon laser was used at $2.0 \%$ power to excite the pMSK1 labeled Alexa488 with a $491-553 \mathrm{~nm}$ band pass filter that collected the emission signal. Image analysis was done with Metamorph (Molecular Devices) using the Multi Wavelength Cell Scoring Application. With this application Metamorph uses the DAPI signal to define the nucleus and then it is able to extract the average intensity inside the nucleus for the green and red channels. Additionally, thresholds were set (15 gray values for green channel, 10 gray values for red channel) that were used to define a cell as positive or negative for that specific channel (percent of positive cells over total cells). The average Pearson coefficient of colocalization was obtained to determine the strength and direction of the linear relationship between phospho-MSK1 and H3S10ph signals that is defined as the signal values divided by their standard deviations.

\section{Transcriptional Factor real-time PCR array}

Total cellular RNA was extracted from the cells using Qiagen RNeasy Mini Kit (SABiosciences) followed by the $\mathrm{RT}^{2}$ First Strand C-03 Kit (SABiosciences) to remove any residual contamination of the RNA samples with $2 \mu \mathrm{g}$ purified RNA per treatment condition. The template combined with the $\mathrm{RT}^{2}$ SYBR green/ROX $\mathrm{qPCR}$ mix (SABiosciences) was loaded into a custom designed 384-well array plate coated with 12 pre-dispensed transcriptional factor gene-specific primer sets (SABiosciences) with four repeats of each treatment condition, and three independent studies on the plate, and processed on a TaqMan ABI Prism 7900 Sequence Detector System (Applied Biosystems) according to the $\mathrm{RT}^{2}$ Profiler PCR Arrays (SABiosciences) manufacturer's protocol. The data analysis was based on the $\Delta \Delta \mathrm{Ct}$ method with normalization to GAPDH (http://www.sabiosciences. $\mathrm{com} /$ pcrarraydataanalysis.php). If the fold changes of treatment group $\Delta \Delta \mathrm{Ct}$ over non-treatment group $\Delta \Delta \mathrm{Ct}$ were larger or equal to 2-fold, the transfection factor would be chosen for further confirmation studies.

\section{Chromatin Immunoprecipitation (ChIP) Assay}

A ChIP assay was performed using SimpleChIP Plus Enzymatic Chromatin IP Kit Cell Signaling) following the protocol outlined by the manufacturer with minor modifications. Briefly, protein and associated chromatin in cells treated with genistein were linked by $1 \%$ formaldehyde for $10 \mathrm{~min}$. After washing with cold PBS, cells were collected by centrifugation and resuspended in SDS lysis 
buffer $(50 \mu \mathrm{M}$ Tris-HCl, $10 \mu \mathrm{M}$ EDTA, $1 \%$ SDS, $1 \mu \mathrm{M}$ PMSF, $10 \mu \mathrm{g} / \mathrm{ml}$ aprotinin and leupeptin) and incubated for $10 \mathrm{~min}$ on ice. The DNA-protein complexes (chromatin-protein) were enzyme digested and sonicated into 200-1000 bp fragments. The fragments were immunoprecipitated with $2 \mu \mathrm{g}$ of antibody against H3S10ph (Cell Signaling) and the DNA fragments associated with H3S10ph were selectively immunoprecipitated, and the associated DNA fragments were purified and subjected to RT-PCR for enrichment of the transcriptional factor promoter regions of EGR1, ELK1, ID1, and MYB (cMyb) using SYBR Premix. The primers (Table 1) were picked by website searches: (http:// www.ncbi.nlm.nih.gov/nuccore/) and (http://www.ncbi.nlm. nih.gov/pubmed/). The primers were located in the promoter region upstream of the TATA or TATA-like box.

\section{Statistical analysis}

To demonstrate whether statistically significant differences existed among different groups of treated or not treated with or without PD, the two-sided t-tests were used to compare $10^{\prime}$ to $0^{\prime}$ and $60^{\prime}$ to 0 ', or 24 to $0 \mathrm{~h}$ and 48 to $0 \mathrm{~h}$ for western blot band intensities. The Mann-Whitney tests [42] were used to compare $10^{\prime}$ to 0 ' and $60^{\prime}$ to 0 ' for western blot band intensities, and were also used to compare treated $10^{\prime}$ and $60^{\prime}$ to not treated $\left(0^{\prime}\right)$ for staining intensity, positive area and colocalization efficiency for confocal Immunofluorescence images. In the immunohistochemistry studies, each patient contributed a tumor sample and a normal tissue sample, therefore, Wilcoxon signed rank tests [43] were used to compare mean staining \% between tumor and normal tissue. For all target transcription factor genes in the real-time RT-PCR studies, the statistical analysis was performed on the normalized values with housekeeping genes using the $\Delta \Delta \mathrm{Ct}$ method. Because all 0 ' fold changes were 1.000 , one-sample t-test [44] was used to test that the $10^{\prime}$ and $60^{\prime}$ fold changes were equal to 1.000 .

\section{Additional files}

Additional file 1: Colocalization of phosphorylated (Phospho-) MSK1 and H3S10ph in ht-UtLM cells treated with genistein $(1 \mu \mathrm{g} / \mathrm{ml})$. The immunofluorescence staining was performed to detect Phospho-MSK1 (green) and H3S10ph (red) colocalization in ht-UtLM cells in the presence or absence of the PD inhibitor following genistein exposure at 0 min (control; shown in Fig. 3a) 10 min. (see Fig. 3a), and 60 min. (60 min. time point was originally part of data set shown in Fig. 3a). (TIF 1048 kb)

Additional file 2: Differential expression of cell proliferation related transcription factor genes induced by genistein $(1 \mu \mathrm{g} / \mathrm{ml})$ in ht-UtLM cells at $24 \mathrm{~h}$ using a Human Transcription Factors $\mathrm{RT}^{2}$ Profiler PCR Array (Qiagen) containing 84 genes. (TIF $1131 \mathrm{~kb}$ )

\section{Acknowledgements}

The authors kindly thank Drs. Wei Qu and Kyathanahalli Janardhan for their critical review of this manuscript. The authors would also like to thank Alicia B. Moore for her excellent assistance with formatting the manuscript. This research was supported by the Intramural Research Program of the $\mathrm{NIH}$, NIEHS and DNTP.

\section{Authors' contributions}

LY: Designed and conducted experiments (western blots, RT-PCR, ChIP assays) collected, analyzed and validated the data. KH, RD: Conducted experiments and analyzed data (immunohistochemistry studies). NF assisted with digital imaging and image analysis studies). XG, LC, RD, YY, CJT: assisted with cell culture treatments, confocal staining, and colocalization coefficiency studies. GEK: performed statistical analysis. LY: Drafted manuscript with help from XG. LY, XG, TKA, DD: Conceived and designed studies, analyzed data, reviewed and revised manuscript for critical intellectual content. All authors read and approved the final document.

\section{Competing interests}

The authors declare that they have no competing interests.

\section{Ethics approval and consent to participate}

Informed consent was obtained, and the Institutional Review Board (IRB) of the National Institute of Environmental Health Sciences, National Institutes of Health approved the study.

\section{Author details}

${ }^{1}$ Molecular Pathogenesis Group, National Toxicology Program (NTP) Laboratory, Division of the NTP (DNTP), National Institute of Environmental Health Sciences (NIEHS), National Institutes of Health (NIH), U.S. Department of Health and Human Services (HHS), Research Triangle Park, North Carolina 27709, USA. ${ }^{2}$ Biostatistics and Computational Biology Branch, Division of Intramural Research (DIR), NIEHS, NIH, HHS, Research Triangle Park, North Carolina 27709, USA. ${ }^{3}$ Signal Transduction Laboratory, DIR, NIEHS, NIH, HHS, Research Triangle Park, North Carolina 27709, USA. ${ }^{4}$ Cellular and Molecular Pathology Branch, DNTP, NIEHS, NIH, HHS, Research Triangle Park, North Carolina 27709, USA. ${ }^{5}$ Chromatin and Gene Expression Group, Epigenetics and Stem Cell Biology Laboratory, DIR, NIEHS, NIH, HHS, Research Triangle Park, North Carolina 27709, USA.

Received: 23 March 2016 Accepted: 17 August 2016

Published online: 31 August 2016

\section{References}

1. Drayer SM, Catherino WH. Prevalence, morbidity, and current medical management of uterine leiomyomas. Int J Gynaecol Obstet. 2015;131(2): $117-22$.

2. Cardozo ER, Clark AD, Banks NK, Henne MB, Stegmann BJ, Segars JH. The estimated annual cost of uterine leiomyomata in the United States. Am J Obstet Gynecol. 2012;206:211 e211-219.

3. Ciarmela P, Islam MS, Reis FM, Gray PC, Bloise E, Petraglia F, Vale W, Castellucci M. Growth factors and myometrium: biological effects in uterine fibroid and possible clinical implications. Hum Reprod Update. 2011;17:772-90.

4. Pollack AZ, Buck Louis GM, Chen Z, Sun L, Trabert B, Guo Y, Kannan K. Bisphenol A, benzophenone-type ultraviolet filters, and phthalates in relation to uterine leiomyoma. Environ Res. 2015;137:101-7.

5. Seo HS, DeNardo DG, Jacquot $Y$, Laios I, Vidal DS, Zambrana CR, Leclerca G, Brown PH. Stimulatory effect of genistein and apigenin on the growth of breast cancer cells correlates with their ability to activate ER alpha. Breast Cancer Res Treat. 2006;99:121-34.

6. Choi EJ, Kim GH. Antiproliferative activity of daidzein and genistein may be related to ERalpha/c-erbB-2 expression in human breast cancer cells. Mol Med Rep. 2013;7:781-4.

7. Moore AB, Castro L, Yu L, Zheng X, Di X, Sifre MI, Kissling GE, Newbold RR, Bortner CD, Dixon D. Stimulatory and inhibitory effects of genistein on human uterine leiomyoma cell proliferation are influenced by the concentration. Hum Reprod. 2007;22:2623-31.

8. Moutsatsou P. The spectrum of phytoestrogens in nature: our knowledge is expanding. Hormones (Athens). 2007;6(3):173-93.

9. Di X, Yu L, Moore AB, Castro L, Zheng X, Hermon T, Dixon D. A low concentration of genistein induces estrogen receptor-alpha and insulin-like growth factor-I receptor interactions and proliferation in uterine leiomyoma cells. Hum Reprod. 2008;23:1873-83.

10. Vitale DC, Piazza C, Melilli B, Drago F, Salomone S. Isoflavones: estrogenic activity, biological effect and bioavailability. Eur J Drug Metab Pharmacokinet. 2013;33:885-91. 
11. Heldring N, Pike A, Andersson S, Matthews J, Cheng G, Hartman J, Tujague M, Strom A, Treuter E, Warner M, Gustafsson JA. Estrogen receptors: how do they signal and what are their targets. Physiol Rev. 2007;87:905-31.

12. Pearce ST, Jordan VC. The biological role of estrogen receptors alpha and beta in cancer. Crit Rev Oncol Hematol. 2004;50:3-22.

13. Lipovka Y, Konhilas JP. The complex nature of estrogen signaling in breast cancer: enemy or ally? Biosci Rep. 2016;36:e00352.

14. Carney SA, Tahara H, Swartz CD, Risinger Jl, He H, Moore AB, Haseman JK, Barrett JC, Dixon D. Immortalization of human uterine leiomyoma and myometrial cell lines after induction of telomerase activity: molecular and phenotypic characteristics. Lab Invest. 2002;82:719-28.

15. Cargnello M, Roux PP. Activation and function of the MAPKs and their substrates, the MAPK-activated protein kinases. Microbiol Mol Biol Rev. 2011;75:50-83.

16. Sun Y, Liu WZ, Liu T, Feng X, Yang N, Zhou HF. Signaling pathway of MAPK ERK in cell proliferation, differentiation, migration, senescence and apoptosis. J Recept Signal Transduct Res. 2015:35:600-4.

17. Arthur JS. MSK activation and physiological roles. Front Biosci. 2008;13:5866-79.

18. Dunn KL, Espino PS, Drobic B, He S, Davie JR. The Ras-MAPK signal transduction pathway, cancer and chromatin remodeling. Biochem Cell Biol. 2005;83:1-14.

19. Espino PS, Li L, He S, Yu J, Davie JR. Chromatin modification of the trefoil factor 1 gene in human breast cancer cells by the Ras/mitogen-activated protein kinase pathway. Cancer Res. 2006;66:4610-6.

20. Vicent GP, Ballare C, Nacht AS, Clausell J, Subtil-Rodriguez A, Quiles I, Jordan A, Beato M. Convergence on chromatin of non-genomic and genomic pathways of hormone signaling. J Steroid Biochem Mol Biol. 2008;109:344-9.

21. Derijard B, Raingeaud J, Barrett T, Wu H, Han J, Ulevitch RJ, Davis RJ. Independent human MAP-kinase signal transduction pathways defined by MEK and MKK isoforms. Science. 1995;267:682-5.

22. Greathouse KL, Bredfeldt T, Everitt JI, Lin K, Berry T, Kannan K, Mittelstadt ML, Ho SM, Walker CL. Environmental estrogens differentially engage the histone methyltransferase $\mathrm{EZH} 2$ to increase risk of uterine tumorigenesis. Mol Cancer Res. 2012;10:546-57.

23. Drobic B, Perez-Cadahia B, Yu J, Kung SK, Davie JR. Promoter chromatin remodeling of immediate-early genes is mediated through $\mathrm{H} 3$ phosphorylation at either serine 28 or 10 by the MSK1 multi-protein complex. Nucleic Acids Res. 2010;38:3196-208.

24. He S, Dunn KL, Espino PS, Drobic B, Li L, Yu J, Sun JM, Chen HY, Pritchard S, Davie JR. Chromatin organization and nuclear microenvironments in cancer cells. J Cell Biochem. 2008;104:2004-15.

25. Dong Z, Bode AM. The role of histone H3 phosphorylation (Ser10 and Ser28) in cell growth and cell transformation. Mol Carcinog. 2006:45:416-21.

26. Espino PS, Pritchard S, Heng HH, Davie JR. Genomic instability and histone $\mathrm{H} 3$ phosphorylation induction by the Ras-mitogen activated protein kinase pathway in pancreatic cancer cells. Int J Cancer. 2009;124:562-7.

27. Bulun SE. Uterine fibroids. N Engl J Med. 2013;369:1344-55.

28. Zhang HM, Li L, Papadopoulou N, Hodgson G, Evans E, Galbraith M, Dear M, Vougier S, Saxton J, Shaw PE. Mitogen-induced recruitment of ERK and MSK to SRE promoter complexes by ternary complex factor Elk-1. Nucleic Acids Res. 2008;36:2594-607

29. Pagel II, Deindl E. Early growth response 1-a transcription factor in the crossfire of signal transduction cascades. Indian J Biochem Biophys. 2011;48: 226-35.

30. Yu L, Moore AB, Castro L, Gao X, Huynh HL, Klippel M, Flagler ND, Lu Y, Kissling GE, Dixon D. Estrogen regulates MAPK-related genes through genomic and nongenomic interactions between IGF-I receptor tyrosine kinase and estrogen receptor-alpha signaling pathways in human uterine leiomyoma cells. J Signal Transduct. 2012;2012:204236.

31. Yordy JS, Muise-Helmericks RC. Signal transduction and the Ets family of transcription factors. Oncogene. 2000;19:6503-13.

32. Ling MT, Wang X, Ouyang XS, Lee TK, Fan TY, Xu K, Tsao SW, Wong YC. Activation of MAPK signaling pathway is essential for Id-1 induced serum independent prostate cancer cell growth. Oncogene. 2002;21:8498-505.

33. Maw MK, Fujimoto J, Tamaya T. Overexpression of inhibitor of DNA-binding (ID)-1 protein related to angiogenesis in tumor advancement of ovarian cancers. BMC Cancer. 2009;9:430.

34. Hong SH, Nah HY, Kim CH. Estrogen-regulated expression and distribution of Id-1 in the mouse uterus. Placenta. 2010:31:240-4
35. Zhou Y, Ness SA. Myb proteins: angels and demons in normal and transformed cells. Front Biosci. 2011;16:1109-31.

36. Kim HG, Lee KW, Cho YY, Kang NJ, Oh SM, Bode AM, Dong Z. Mitogen- and stress-activated kinase 1-mediated histone $\mathrm{H} 3$ phosphorylation is crucial for cell transformation. Cancer Res. 2008;68:2538-47.

37. Yu L, Saile K, Swartz CD, He H, Zheng X, Kissling GE, Di X, Lucas S, Robboy SJ, Dixon D. Differential expression of receptor tyrosine kinases (RTKS) and IGF-I pathway activation in human uterine leiomyomas. Mol Med. 2008;14: 264-75.

38. Petroff BK, Clark JL, Metheny T, Xue Q, Kimler BF, Fabian CJ. Optimization of estrogen receptor analysis by immunocytochemistry in random periareolar fine-needle aspiration samples of breast tissue processed as thin-layer preparations. Appl Immunohistochem Mol Morphol. 2006;14:360-4.

39. Detre S, Saclani Jotti G, Dowsett M. A "quickscore" method for immunohistochemical semiquantitation: validation for oestrogen receptor in breast carcinomas. J Clin Pathol. 1995:48:876-8.

40. Dixon D, He H, Haseman JK. Immunohistochemical localization of growth factors and their receptors in uterine leiomyomas and matched myometrium. Environ Health Perspect. 2000;108 Suppl 5:795-802.

41. Hermon TL, Moore AB, Yu L, Kissling GE, Castora FJ, Dixon D. Estrogen receptor alpha (ERalpha) phospho-serine-118 is highly expressed in human uterine leiomyomas compared to matched myometrium. Virchows Arch. 2008;453(6):557-69.

42. Conover W. Practical nonparametric statistics. New York: John Wiley \& Sons Incorporated: 1999.

43. Conover W. Practical nonparametric statistics. New York: John Wiley \& Sons Incorporated; 1971.

44. Sokal RR, Rohl FJ. Biometry. New York: W.H. Freeman and Company; 1995.

\section{Submit your next manuscript to BioMed Central and we will help you at every step:}

- We accept pre-submission inquiries

- Our selector tool helps you to find the most relevant journal

- We provide round the clock customer support

- Convenient online submission

- Thorough peer review

- Inclusion in PubMed and all major indexing services

- Maximum visibility for your research

Submit your manuscript at www.biomedcentral.com/submit
Biomed Central 